\title{
CLIMATE CHANGE RISKS AND TOURISM IN SOUTH AFRICA: PROJECTIONS AND POLICY
}

\author{
Wayde R. PANDY \\ University of Johannesburg, School of Tourism \& Hospitality, Johannesburg, South Africa, email: wayde360@gmail.com \\ Christian M. ROGERSON* \\ University of Johannesburg, School of Tourism \& Hospitality, Johannesburg, South Africa, email: chrismr@uj.ac.za
}

\begin{abstract}
Citation: Pandy, W.R., \& Rogerson, C.M. (2021). CLIMATE CHANGE RISKS AND TOURISM IN SOUTH AFRICA: PROJECTIONS AND POLICY. GeoJournal of Tourism and Geosites, 35(2), 445-455. https://doi.org/10.30892/gtg.35224-671
\end{abstract}

\begin{abstract}
The challenge of climate change and tourism is an evolving international knowledge domain. South Africa is one of the most vulnerable countries with respect to projected climate change. For the national tourism economy climate change is a significant topic of concern. The objectives in this article are to present climate change projections and potential impacts for South Africa's tourism economy and to critically analyse the policy landscape concerning national government's response to climate change as a whole and more specifically in relation to the tourism sector. It is shown key tourism assets of South Africa are at risk from the advance of climate change. The analysis discloses that the South African government has supported international efforts and obligations to address the challenge of climate change, commitments which have influenced policy development regarding tourism. Nevertheless, policy development towards climate change and tourism has not progressed greatly over the past decade. Arguably, this is an outcome of the overwhelming concentration in recent government tourism policy in South Africa towards issues of inclusivity and transformation.
\end{abstract}

Key words: climate change, climate risks, tourism policy, South Africa

$* * * * * *$

\section{INTRODUCTION}

With record-breaking weather events relating to rainfall extremes, global temperate trends, and the decade 2010-2019 being recognised as the hottest on record it is evident that our climate is changing (Conway and Vincent, 2021). The phenomenon of climate change is projected to fundamentally alter or undermine the natural resource base upon which many forms of tourism are built and reliant (Gómez-Martín, 2005; Saarinen et al., 2012; Kilungu et al., 2019). Importantly, its interactions and implications differ across space and time as climate change increases previously identified risk patterns whilst also unleashing new types of risk that extend to regions previously not considered as at risk (Mortreux and Barnett, 2009). As the tourism industry makes use of physical space and environmental conditions climate change has the capacity to impact and in some instances to undermine the development or continued sustainability of the industry at certain locations (Gómez-Martín, 2005; Tervo-Kankare et al., 2018). Indeed, climate change has critical ramifications most especially for tourism-dependent communities and livelihoods in locations where tourist-related development has become a critical component of local, regional and national economies (Scott et al., 2019). As one of the largest contributing industries to global warming, the tourism industry has an important role to play in reducing and mitigating environmental impacts in order to avoid extremely dangerous levels of climate change being reached while still crucially maintaining the growth and profitability that have made the industry such an important source of employment and economic development (Gössling et al., 2012). Over recent years the study and relationship between tourism and climate change is one that has triggered increased academic interest across several disciplines (Ruhanen and Shakeela, 2013; Hoogendoorn and Fitchett, 2016; Sinclair-Maragh, 2016; Pandy, 2017; Sifolo and Henama, 2017; Fang et al., 2018). For tourism scholars issues relating to climate change increasingly are leading items on the research agenda (Scott et al., 2019). The challenge of climate change and tourism is an evolving international knowledge domain (Hall, 2008; Scott, 2008; Becken, 2013; Pang et al., 2013; Shakeela and Becken, 2015; Nacipucha et al., 2017; Pandy, 2017; Mushawemhuka et al., 2018). Prideaux et al. (2020) aver that lessons from the COVID-19 pandemic should prepare global tourism for the economic transformation needed to combat climate change.

For the South African tourism economy climate change is a significant topic of concern. Geographers have been particularly at the forefront of tourism and climate change research (Rogerson and Visser, 2020). This paper extends a growing scholarship about tourism and climate change in South Africa (Steyn and Spencer, 2012; Hoogendoorn et al., 2016; Rogerson, 2016; Giddy et al., 2017; Pandy, 2017; Fitchett and Hoogendoorn, 2018; Hoogendoorn and Fitchett, 2018; Pandy and Rogerson, 2018; Fitchett and Mahlangu, 2019; Pandy and Rogerson, 2019; Dube et al., 2020; Pandy and Rogerson, 2020; Dube et al., 2021; Fitchett, 2021). The two aims for this paper are as follows. First, is to present climate change projections and potential impacts for South Africa's tourism economy. Second, is to critically analyse the policy landscape in South Africa concerning national government's response to climate change as a whole and more specifically in relation to the tourism sector. As is argued by Adu-Ampong et al. (2021) a focus on the climate change-tourism policy nexus is 
vital when reconsidering the agenda of sustainability for sub-Saharan Africa. In terms of sources and methods the projected implications of climate change for South Africa are critically reviewed by triangulating information from the Intergovernmental Panel on Climate Change (IPCC) and other climate science research on South Africa (Department of Science and Technology, 2010; Department of Environmental Affairs, 2013; Carabine et al., 2014; Department of Environmental Affairs, 2016). National government's response is explored through investigating policy documents, a critical review and evaluation of the country's climate change related policy and of specific policy developments related to tourism.

\section{Climate Change Risks for South Africa}

At the outset of examining climate change and tourism it is observed South Africa experiences a significant variety of weather and climate based conditions which in combination produce inter-annual variation across different regions of the country (Tyson and Preston-Whyte, 2000). As a result of being located between $35^{\circ}$ south and $22^{\circ}$ south, the country's global location sees subtropical high-pressure systems influence South Africa's overall rainfall patterns, while also being affected by the El Niño and La Niña climate cycles (Department of Science and Technology, 2010). Experiencing mean annual temperatures which exceed $17^{\circ} \mathrm{C}$, South Africa is recognised as having a relatively warm climate which is influenced by a combination of location, topography, and the different ocean currents which surround the country (Davies, 2016). South Africa experiences seasonal variations in weather and climate as well. The country's interior is predominantly elevated on a plateau which at its highest reaches a height of 1250 meters above sea-level. The outcome of several factors is to create complex patterns of national, regional and local weather and in the long-term, climate (Department of Science and Technology, 2010), which in turn have significant implications for the types of tourism that can be undertaken within the country (Fitchett et al., 2017). Research by climate scientists assists understanding the impacts and implications of climate change on South Africa (Conway and Vincent, 2021). Studies examining five decades of climate based information from 1960-2010 reveal important trends for the country, most significantly annual temperatures have increased by 1.5 times the global average over this period (Golder Associates, 2012). The result is that South Africa's annual temperature has increased at a faster rate than the world average for the same period (Ziervogel et al., 2014). Furthermore, such increases in temperature appear to have occurred across all seasons with the exception of a single zone within the country's central interior. It is recorded that the highest rates of temperature increase occurred between 1970 -1980 and again between 1990 and the early 2000s (Department of Environmental Affairs, 2013).

\section{Mean annual temperature recordings and projections for the country of South Africa}

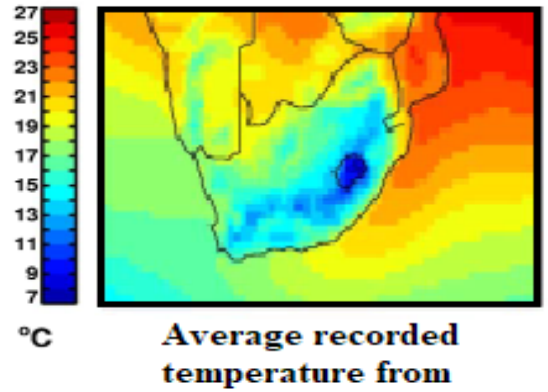

1971-2000

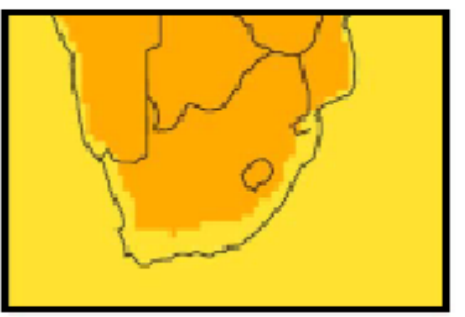

Projected outcome of a $1.5^{\circ} \mathrm{C}$ temperature increase

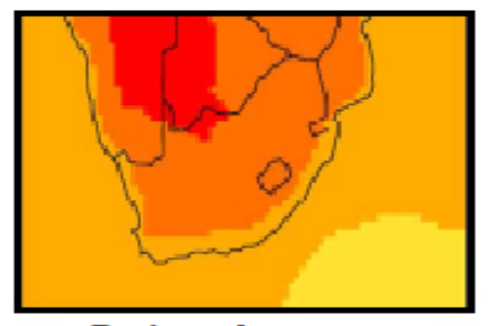

Projected outcome of a $2^{\circ} \mathrm{C}$

temperature increase

Figure 1. Mean annual values of the recorded temperatures for the region of southern Africa observed between 1971 and 2000 , along with projected temperature increases of $1.5^{\circ} \mathrm{C}$ and $2{ }^{\circ} \mathrm{C}$ (Source: Maúre et al., 2018)

The critical changes impacting South Africa's weather and climate from 1960-2010 are the baseline observations used to project future climate outcomes for the country which use multiple climate models (Nicholson et al., 2018). Based primarily on the IPCC's fifth assessment reports, localised South Africa's General Circulation Modelling highlights specific challenges that the country faces with regards to rising temperatures, decreasing regional water availability and distribution, along with an increase in fire and flood based extreme events (Department of Environmental Affairs, 2013). The climate change based LongTerm Adaptation Scenario technical working group has focussed on four key potential scenarios as a consequence of climate change (Department of Science and Technology, 2017). The projections are for temperature increases within the central interior, while coastal regions are predicted to also see an increase in temperature albeit to a lesser extent (Romero-Lankao et al., 2018). It is suggested that in the short-term South Africa should prepare for temperature increase of between $1{ }^{\circ} \mathrm{C}$ and $2^{\circ} \mathrm{C}$, while also facing a potential increase of $4^{\circ} \mathrm{C}$ in the long-term if emissions trends continue at their current rate (Carabine et al., 2014). Moreover, it is noted that in the instance that emissions trends increase at more than the current rate, long-term climate change scenarios predict that South Africa could see as much as a temperature increase of $7^{\circ} \mathrm{C}$ in some areas of the country with significant increase in the number of days throughout the year when temperatures regularly exceed $35^{\circ} \mathrm{C}$ (Engelbrecht et al., 2019). In seeking to better understand the relationship between temperature changes and the country's precipitation, it was observed that direct comparisons taken over the same period tend to reveal weak overall trends as a result of the highly variable nature of annual rainfall (MacKellar et al., 2014). Such comparisons do, however, reveal a general tendency towards a decrease in the number of rain days experienced across all areas of the country, while also noting a disturbing increase in the levels of intensity associated with rainfall events. Overall, therefore, the observed trend is for a decrease in total rainfall throughout South Africa with increases in rainfall storm intensity (Rogerson, 2016). These findings are mapped on Figures 2 and 3 below. It is critical to note that the western parts of the country traditionally rely on the winter-based precipitation whilst the eastern half of 
South Africa predominantly relies on summer rainfall (Steyn and Spencer, 2012). A number of climate models project a significant decrease in rainfall for the western half of the country largely depending on (among other factors), the extent of future carbon emissions globally, real time temperature increases, and global circulation patterns (Department of Environmental Affairs, 2016). For an already water-stressed country, these critical projections for rainfall decrease have enormous potential consequences for South Africa's population and economy, and not least for the tourism industry (Department of Environmental Affairs, 2011).

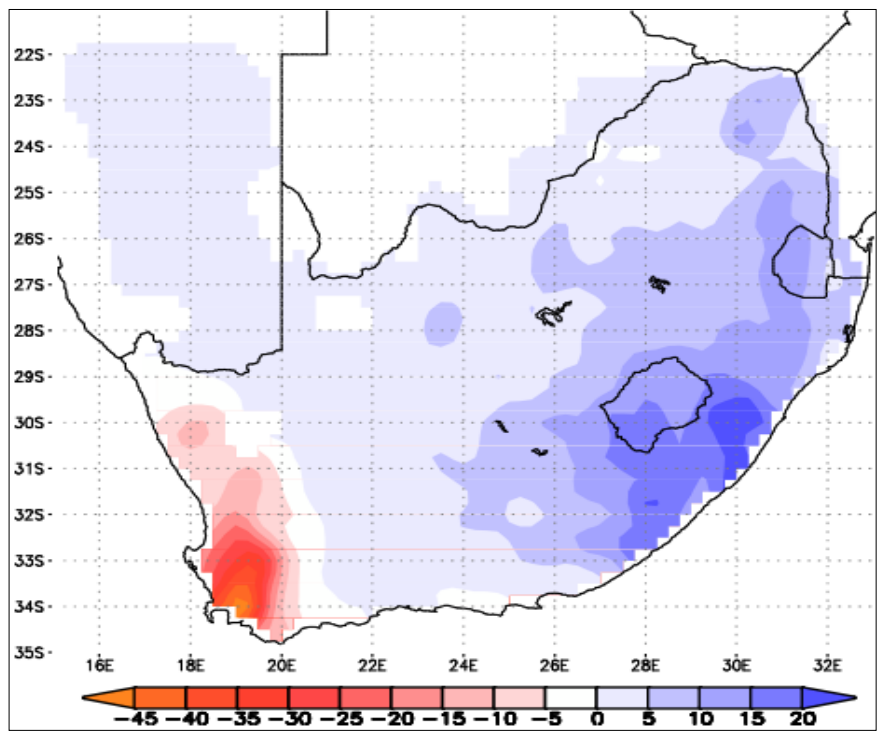

Figure 2. Projected total precipitation for

South Africa's winter month of July (Source:

Department of Environmental Affairs and Tourism, 2007)

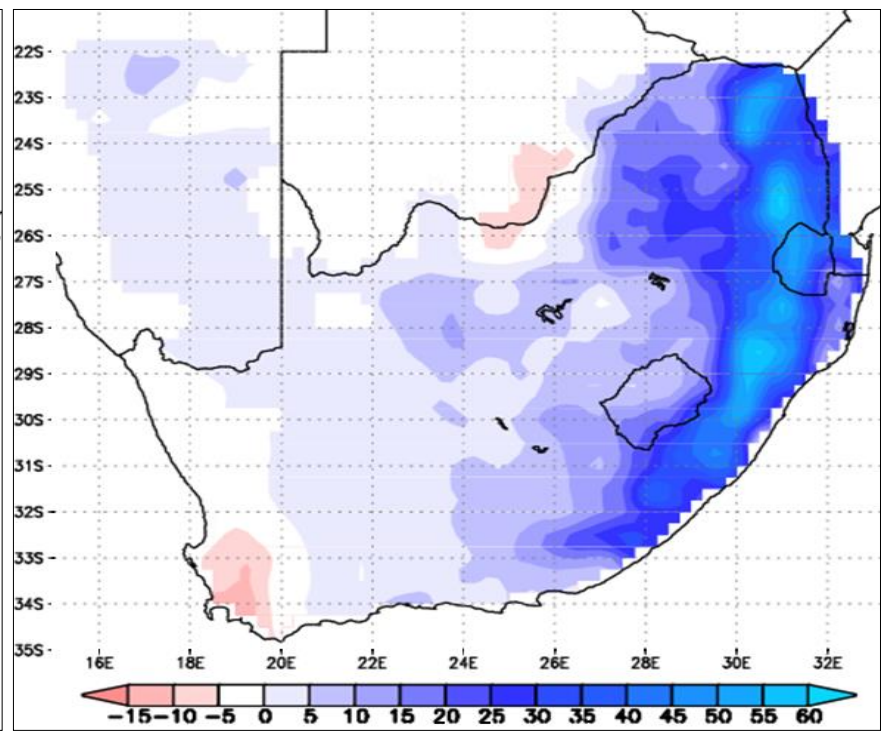

Figure 3. Projected total precipitation for South Africa summer month of December (Source: Department of Environmental Affairs and Tourism, 2007)

It is documented widely that climate change will have a wide range of impacts on urban, rural and coastal areas throughout South Africa (Ziervogel et al., 2010). Predicted flooding for certain urban areas of South Africa has significant ramifications for infrastructure and disruption to transport networks (World Bank, 2018). Further, as a result of increased temperatures, it is projected climate change has the potential to significantly reduce the levels of air quality by trapping high concentrations of pollution which cities produce in significant quantities (Bai et al., 2018). In assessing the impact of climate change on rural areas, it should be highlighted that rural economies in South Africa are seen as being "primarily dependent on agriculture, herding, and tourism" (Department of Environmental Affairs, 2013: 36), which with mining provide the majority of formal sector economic opportunities for rural populations.

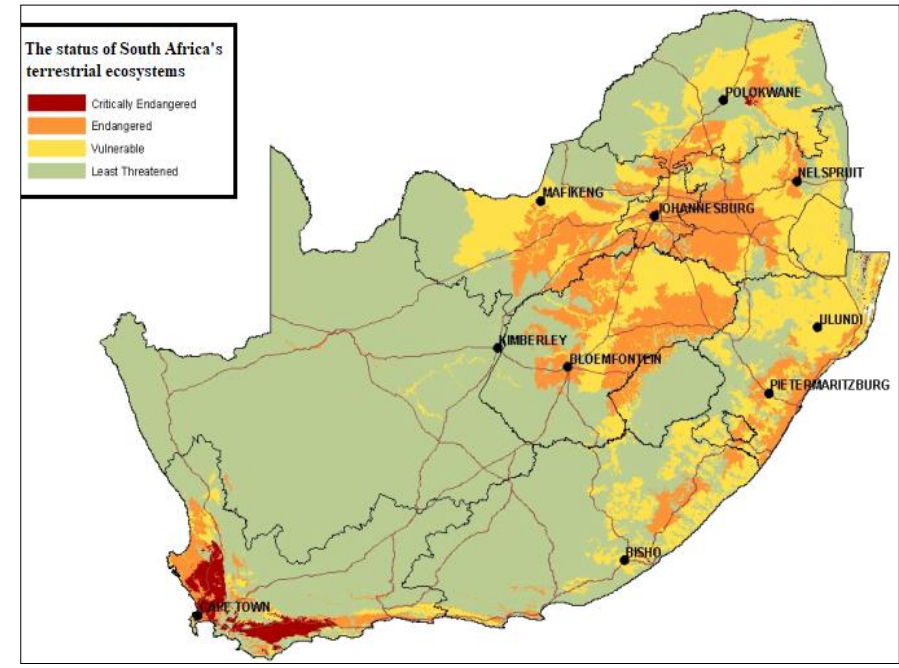

Figure 4. The status of South Africa's terrestrial ecosystems (Source: Driver et al, 2004)

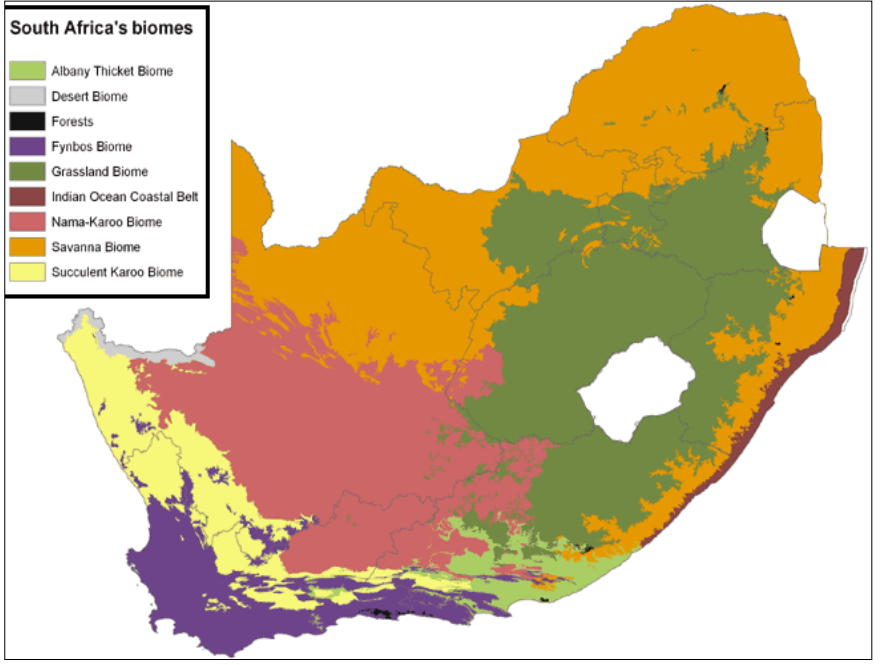

Figure 5. South Africa's Biomes

(Source: Department of Environmental Affairs, 2018)

Rural areas are observed to face similar issues to cities in terms of damage and disruption caused by climate change related events, albeit face higher levels of vulnerability given their infrastructure deficits, constrained financial resource base and capacity shortcomings of local governments (Ofoegbu et al., 2017; Conway and Vincent, 2021). Moreover, as tourism in rural areas in South Africa places particular emphasis on products which are closely reliant on the natural environment, such segments of tourism are highly vulnerable to the impacts of climate change projected to adversely affect the country's biodiversity (Rogerson, 2016). It has been recognised by the Department of Environmental Affairs (2013) that climate change 
related impacts which serve to damage or degrade the country's national environment, its beauty and the function of key biomes or ecosystems represent a significant threat to South Africa's overall tourist economy. Madzwamuse (2010: 7) records that the impact of climate change on animal life in natural environments may be affected and see a decline "by as much as $10 \%$ due to drought, bush encroachment, malnutrition and disease". A critical outcome is to negatively impact the country's international tourism image around outdoor and unique nature-based experiences (Hoogendoorn and Fitchett, 2018).

Figure 4 reveals the status of the country's terrestrial ecosystems according to the country's first National Spatial Biodiversity Assessment (Driver et al., 2004). It is evident ecosystems nearest to the South Africa's major urban areas face increasing pressure. Of special significance is the ecosystems around the city of Cape Town; here some ecosystems are classified as critically endangered which raises key concerns for the country's most popular and iconic international tourism destination (Driver et al., 2004). Figure 5 maps the distinctive biomes of the country. From the perspective of biodiversity, South Africa which relies heavily on the natural environment as a key component of the country's tourism product, is ranked as having the third highest level of biodiversity in the world (Driver et al., 2004). Although the country represents only " $2 \%$ of the world's land area", South Africa is still "home to nearly $10 \%$ of the world's plants and $7 \%$ of the reptiles, birds and mammals" (Driver et al., 2004: 3). This makes essential the assessment, planning and implementation of climate change related mitigation and adaptation, not least because both the country's population and tourists rely on the existence of healthy functioning ecosystems, which provide a range of critical services that healthy populations require (Department of Environmental Affairs, 2013). Indeed, healthy ecosystems play a critical role in the catchment and subsequent storage of water, clean air, and in some instances erosion and flood control. The country further requires healthy ecosystems in order to provide basic resources which underpin the South African economy, while many of the country's poor also rely on access to commonly available resources as a means of basic survival as well (Madzwamuse, 2010). In unpacking the projected impacts of climate change, coupled with unsustainable socio-economic activities, the country's Grassland biome and the Indian Ocean Coastal Belt biome have been identified as being the two biological communities at the greatest level of risk. Climate change in South Africa represents a threat also to thousands of plant and animal species, some of which are unique to the country and represent major assets for the tourism economy. This diversity of vegetation types is a central tourism asset for South Africa which requires serious consideration in order to ensure that such a natural base is kept intact (Department of Tourism, 2011a). From a conservation perspective there are challenges which derive from the fact that when the country's earliest conservation areas were first established many were based in or around areas with little economic importance. As a result, the majority of the country's protected areas were not established to conserve significant proportions of the country's nine biomes. As a consequence this leaves many key segments of the natural environment, and key biomes formally unprotected (Driver et al., 2012).

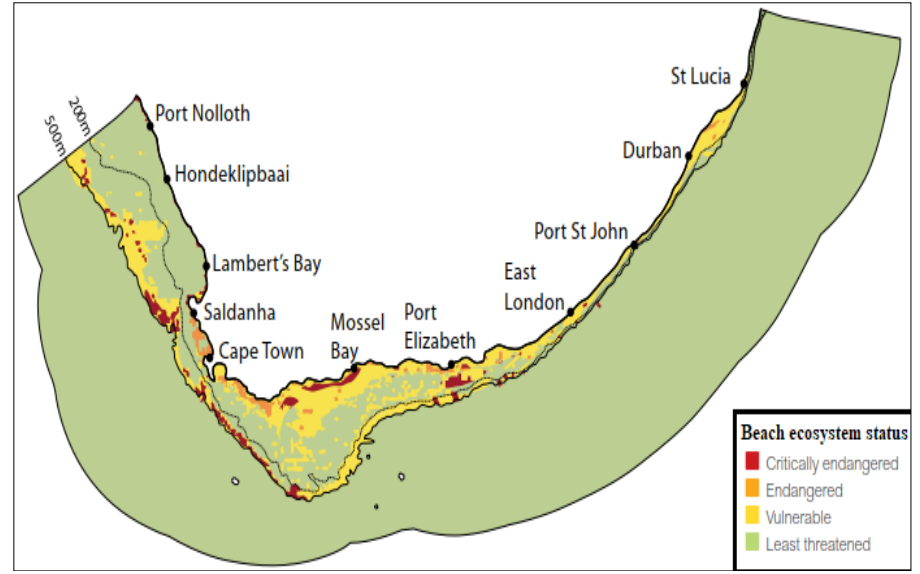

Figure 6. The status of South Africa's beach based ecosystems (Source: Driver et al., 2004)

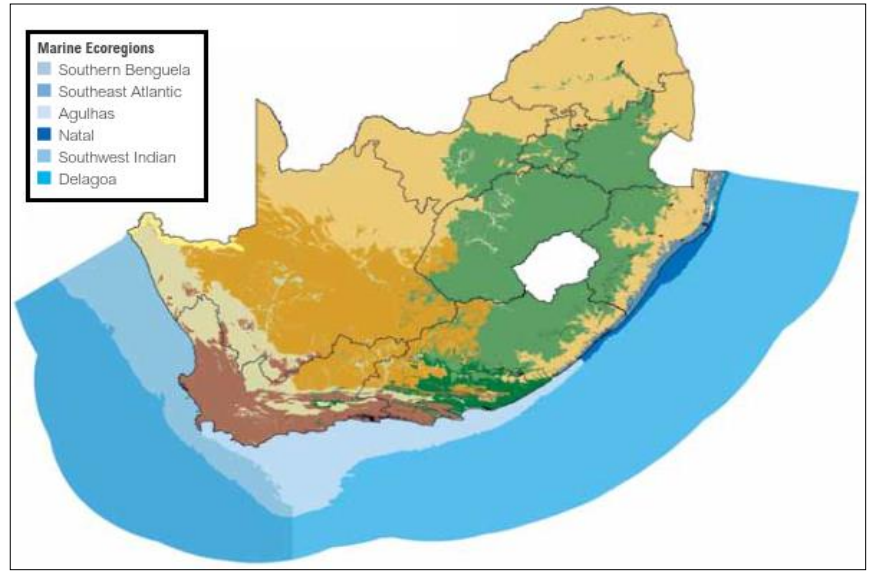

Figure 7. South Africa's Marine-based Ecoregions (Source: Driver et al., 2004)

Certain specific climate change related challenges are projected to impact the country's coastal and ocean based marine ecosystems (Rogerson, 2020; Dube et al., 2021). South Africa's coastal areas and oceans represent a vital resource for the country's tourism economy (Rogerson and Rogerson, 2020). In this regard it has been estimated that in the pre-COVID-19 period beach and ocean based marine tourism alone contributed an estimated R 13.5 billion annually in South Africa (Driver et al., 2012). Marine and coastal tourism activities include beach leisure, whale and dolphin watching excursions, shark cage diving, SCUBA diving and recreational fishing (Giddy and Rogerson, 2018; McKay, 2020; Rogerson and Rogerson, 2020a). In discussing the potential impacts of climate change on South Africa's coastal terrestrial areas it is important to note the projected issues associated with sea-level rise and increases in extreme events such as larger and more frequent storm surges with dangers for coastal flooding (Department of Tourism, 2011a; Dube et al., 2020, 2021). Such events while directly impacting immediately on tourism by discouraging coastal based activities, are also projected to have a range of other issues and impacts such as damaging crucial infrastructure which tourism makes use of, the introduction of salt water into fresh water resources, and increased erosion of beaches (Driver et al., 2004). Further, there are several low-lying tourism locations which are projected to be impacted including beaches along the Western Cape Garden Route, and sections of the KwaZulu-Natal coast (Department of Environmental Affairs, 2011). The outcomes of climate change may have severe consequences for the many tourism dependent destinations in such affected areas (Figure 6). Beyond South Africa's terrestrial biomes, the country has also 
been identified as having six key marine ecoregions which include 136 different types of marine habitats within the country's international boundaries (Figure 7). It is calculated that $41 \%$ of these offshore ecosystem types are threatened (Driver et al., 2004). Moreover, it is observed that the most threatened of all habitats near to the shoreline tend to be those associated with rock shores or reef habitats, while the offshore ecoregions of the Southern Benguela and Agulhas are in the greatest threat of increasing sea-temperatures which will have profound consequences for plants and animal life (Carabine et al., 2014).

Table 1. Climate risk factors and potential impacts (Source: Department of Tourism, 2011a)

\begin{tabular}{|c|c|c|c|c|c|}
\hline $\begin{array}{c}\text { Projected } \\
\text { Change }\end{array}$ & Services and energy & Human Health & $\begin{array}{l}\text { Food security, water } \\
\text { and agriculture }\end{array}$ & Business continuity & Biodiversity \\
\hline $\begin{array}{l}\text { An increase } \\
\text { of } \mathrm{O}-1.5^{\circ} \mathrm{C} \\
\text { in daily } \\
\text { maximum } \\
\text { temperatures } \\
\text { for January } \\
\text { and } 0- \\
1.5^{\circ} \mathrm{C} \text { in } \\
\text { daily } \\
\text { minimum } \\
\text { temperatures } \\
\text { for July }\end{array}$ & $\begin{array}{l}\text { - Increase in } \\
\text { requirements for cooling } \\
\text { (air conditioning in } \\
\text { summer) } \\
\text { - Decrease in heating } \\
\text { requirements in winter } \\
\text { - Higher rates of refuse } \\
\text { decay - more frequent } \\
\text { waste collection required } \\
\text { - Greater number of fires } \\
\text { - service disruption and } \\
\text { damage }\end{array}$ & $\begin{array}{l}\text { - Increase in heat-related vector } \\
\text { and water-borne illnesses } \\
\text { - Possible spread malaria to } \\
\text { previously unaffected areas } \\
\text { (dependent on maintenance of } \\
\text { spraying programmes) } \\
\text { - Increase in requirements for } \\
\text { cooling (air conditioning in } \\
\text { summer) } \\
\text { - Decrease in heating } \\
\text { requirements in winter } \\
\text { - Heat stress } \\
\text { - Deteriorating air quality due } \\
\text { to different dispersion patterns } \\
\text { - Exacerbation of poverty, } \\
\text { crime } \\
\text { - Greater number of fires - } \\
\text { safety hazard }\end{array}$ & $\begin{array}{l}\text { - Damage to crops } \\
\text { - Need for better food } \\
\text { hygiene (refrigeration) } \\
\text { - Land use conflicts } \\
\text { between agricultural } \\
\text { land and conservation } \\
\text { areas used for tourism } \\
\text { - Changes in demand, } \\
\text { supply, and quality of } \\
\text { water } \\
\text { - Increased demand for } \\
\text { water for irrigating } \\
\text { green spaces (golf } \\
\text { courses, parks) } \\
\text { - Loss of certain crops }\end{array}$ & $\begin{array}{l}\text { - Larger numbers of } \\
\text { visitors to coastal } \\
\text { areas due to these } \\
\text { areas having less } \\
\text { extremes in } \\
\text { temperatures - } \\
\text { pressure on } \\
\text { infrastructure and } \\
\text { services }\end{array}$ & $\begin{array}{l}\text { - Impacts on species } \\
\text { /ecosystem goods and } \\
\text { services which affect } \\
\text { tourist attractions } \\
\text { - Increase in the } \\
\text { number and extent of } \\
\text { invasive species in } \\
\text { natural areas } \\
\text { - Altitudinal migration } \\
\text { of species } \\
\text { - Extended range of } \\
\text { pests and diseases }\end{array}$ \\
\hline $\begin{array}{l}\text { Increased } \\
\text { frequency } \\
\text { and intensity } \\
\text { of short } \\
\text { duration } \\
\text { heavy rains }\end{array}$ & $\begin{array}{l}\text { - Local flooding, storm } \\
\text { water overflow and } \\
\text { ground and surface water } \\
\text { pollution } \\
\text { - Stress on sewage }\end{array}$ & $\begin{array}{l}\text { - Basement and foundation } \\
\text { level flooding } \\
\text { - Breeding of malaria and } \\
\text { cholera vectors in ponding } \\
\text { water }\end{array}$ & $\begin{array}{l}\text { - Damage to crops and } \\
\text { reliability of harvest } \\
\text { food supply } \\
\text { - Changes in demand, } \\
\text { supply, and quality of } \\
\text { water } \\
\text { - Affected ability of } \\
\text { dams to store and } \\
\text { capture water } \\
\text { - Erosion and } \\
\text { sedimentation in green } \\
\text { areas }\end{array}$ & $\begin{array}{l}\text { - Golf courses, open } \\
\text { space systems and } \\
\text { other tourism } \\
\text { infrastructure at risk } \\
\text { of flooding } \\
\text { - Disruption of access } \\
\text { routes } \\
\text { - Increased insurance } \\
\text { claims or inability to } \\
\text { obtain insurance } \\
\text { - Increase in business } \\
\text { risk and emergency } \\
\text { situations }\end{array}$ & $\begin{array}{l}\text { - Parks and green } \\
\text { spaces provide flood } \\
\text { attenuation }\end{array}$ \\
\hline $\begin{array}{l}\text { Prolonged } \\
\text { periods with } \\
\text { no rain and } \\
\text { heat waves }\end{array}$ & $\begin{array}{l}\text { - Stress on sewage } \\
\text { systems } \\
\text { - Infrastructure heat } \\
\text { stress } \\
\text { - Increased cooling } \\
\text { energy demand } \\
\text { - Reduction in heating } \\
\text { requirements } \\
\text { - Increase in emergency } \\
\text { services }\end{array}$ & $\begin{array}{l}\text { - Increase in cooling load } \\
\text { - Increase in individual and } \\
\text { family risk and emergency } \\
\text { situations } \\
\text { - Increased load on health } \\
\text { care facilities }\end{array}$ & $\begin{array}{l}\text { - Reduced food } \\
\text { production } \\
\text { - Changing disease } \\
\text { vectors and possible } \\
\text { increase in food } \\
\text { poisoning } \\
\text { - Increased water } \\
\text { demand and purification } \\
\text { requirements } \\
\text { - Increase in water } \\
\text { borne diseases }\end{array}$ & $\begin{array}{l}\text { - Fewer visitors due } \\
\text { to higher } \\
\text { temperatures and } \\
\text { drought } \\
\text { - Business risk to } \\
\text { reduced water } \\
\text { availability }\end{array}$ & $\begin{array}{l}\text { - Stress on green } \\
\text { spaces and the critical } \\
\text { loss of flood } \\
\text { attenuation amongst } \\
\text { other services }\end{array}$ \\
\hline $\begin{array}{l}\text { Sea level } \\
\text { rise }\end{array}$ & $\begin{array}{l}\text { - Increased erosion, and } \\
\text { coastal flooding of } \\
\text { infrastructure - access } \\
\text { routes, buildings, } \\
\text { services }\end{array}$ & $\begin{array}{l}\text { - Inundation of coastal } \\
\text { resorts }\end{array}$ & $\begin{array}{l}\text { - Salination of } \\
\text { agricultural lands - } \\
\text { lower productivity } \\
\text { - Disruption to } \\
\text { estuarine functioning } \\
\text { - change in marine } \\
\text { ecosystems and } \\
\text { attractions } \\
\text { - Water supply and } \\
\text { wastewater disposal } \\
\text { disruption }\end{array}$ & $\begin{array}{l}\text { - Impact on } \\
\text { beaches/tourist } \\
\text { attractions } \\
\text { Inability to obtain } \\
\text { insurance }\end{array}$ & $\begin{array}{l}\text { - Permanent inundation } \\
\text { of some natural } \\
\text { ecosystems } \\
\text { - Expected coastal } \\
\text { erosion will increase the } \\
\text { impacts on coastal } \\
\text { vegetation which could } \\
\text { potentially include } \\
\text { destruction and } \\
\text { displacement of } \\
\text { sensitive dune } \\
\text { vegetation leaving } \\
\text { coastal infrastructure } \\
\text { vulnerable } \\
\end{array}$ \\
\hline $\begin{array}{l}\text { Carbon } \\
\text { pressures }\end{array}$ & $\begin{array}{l}\text { - Pressure to reduce } \\
\text { energy and carbon } \\
\text { emissions (could be } \\
\text { positive in terms of energy } \\
\text { cost savings) } \\
\text { - Carbon taxes could } \\
\text { affect facility profitability } \\
\text { - Carbon pressure on long } \\
\text { haul flights could reduce } \\
\text { passenger numbers } \\
\text { coming to SA (especially } \\
\text { from traditional markets of } \\
\text { UK and Europe) }\end{array}$ & $\begin{array}{l}\text { - Pressure to use less energy } \\
\text { (lower service delivery } \\
\text { levels, air conditioning, } \\
\text { transport, electricity supply) }\end{array}$ & $\begin{array}{l}\text { - Import of food } \\
\text { constrained ("food } \\
\text { miles") }\end{array}$ & $\begin{array}{l}\text { - Need for changes } \\
\text { in transport modes } \\
\text { (away from motor } \\
\text { vehicles) } \\
\text { - Carbon taxes } \\
\text { could discourage } \\
\text { people from } \\
\text { utilising private } \\
\text { vehicles }\end{array}$ & $\begin{array}{l}\text { - Atmospheric carbon } \\
\text { affecting species } \\
\text { distributions - woody } \\
\text { and invasive species } \\
\text { favoured and } \\
\text { encroachment into } \\
\text { grassland areas, } \\
\text { affecting traditional } \\
\text { tourist attractions and } \\
\text { game viewing }\end{array}$ \\
\hline
\end{tabular}




\section{Climate Change and Risks for Tourism in South Africa}

Overall, the most detailed baseline assessment of the impact of climate change on South Africa's tourism economy is the report produced by Golder Associates (2011) which was commissioned by the national Department of Tourism in order to inform its policy responses to climate change. The implications of climate change for South Africa's tourism economy according to this influential report, are substantial and multi-faceted. These are summarised on Table 1.

In a workshop held with key tourism stakeholders several key conclusions emerged about the potential implications for climate change for South Africa's tourism economy. In discussing the potential impacts associated with climate change on the tourism industry with a cross-section of the country's tourism stakeholders it was highlighted that the majority of private tourism operators and organisations had limited or no engagement with the issue of climate change. It was recorded "climate change issues are not discussed at the various levels within the sector" and instead are frequently drowned out by a range of other issues that are seen as taking greater priority (Department of Tourism, 2011a: 32). The primary reason related to the state of the tourism economy at the time, and the fact that a number of stakeholders in the industry were experiencing increasing financial pressures as a result of decreasing tourist numbers with downturns in both domestic and international tourism. Moreover, the industry also appeared to be focused on complying with national government driven transformation initiatives which sought to make the tourism industry more inclusive (Abrahams, 2019). Within this policy context the industry stakeholders viewed climate change-based sustainability initiatives as nothing more than 'a nice to have' rather than being essential to the long-term survival or profitability of the tourism industry (Pandy and Rogerson, 2018, 2020).

In discussing climate change related topics within the context of mitigation initiatives such as recording, reporting and ultimately reducing the tourism industry's carbon emissions footprint, it emerged that an action such as carbon emissions reporting was "perceived to be largely for internal purposes, as an ethical initiative" and nothing more (Department of Tourism, 2011a: 32). It was suggested by industry stakeholders that a great deal of 'uncertainty' surrounding how to calculate carbon emissions accurately exists, along with a lack of surety as to how to report such emissions effectively. This said, it was disclosed that members of the tourism industry felt optimistic that over time as such initiatives become increasingly common and the requisite stakeholders gain experience that actions such as carbon emissions recording and reporting would become entrenched as a standard industry practice. This is not to suggest that no action had been forthcoming or undertaken by the tourism industry with regards to reducing carbon emissions, but instead that the main motivating factors behind such efforts had little to do with climate change-based considerations. Instead, it was revealed industry action that resulted in reduced carbon emissions emerged as 'a lucky by-product' of initiatives undertaken to primarily reduce operating costs incurred as a result of significantly rising energy prices throughout the country (see Rogerson and Sims, 2012; Ismail and Rogerson, 2016). Furthermore, it was acknowledged that the majority of industry-based training initiatives specifically focussed on cost-cutting initiatives within the bounds of hospitality focussed skills and knowledge development, with climate change or sustainability based initiative going largely ignored. Golder Associates (2012) attempted to understand the position of key South African tourism stakeholders regarding the issues of climate change vulnerability and the potential need for adaptive actions by industry organisations and service providers. In paying cognisance to the types or locations within South Africa's tourism regarded by the industry as being particularly vulnerable to climate change related impacts, stakeholders identified the coastlines of KwaZulu Natal and the Eastern Cape, along with marine related wildlife and attractions spread out along South Africa's coastal waters. In addition, the risks posed to the natural environments that make up some of the country's iconic conservation park areas as the Kruger National Park were pinpointed. In the Western Cape Province, concern surrounding the province's rare and famous fynbos related flora, fauna and conditions for wine estates or wine-based tourism. In the Northern Cape's Namaqualand based conservation areas concerns related to the natural environment. Other issues of concern surrounded disruption of the transport sector, water shortages, food availability and spread of vector-borne diseases, most notably of malaria. The direct impacts associated with increases in average daily temperatures, which the industry associated with increasing energy costs as infrastructure related demands as well as higher levels of discomfort for tourists (Golder Associates, 2012).

In a recent report the World Bank (2018) identifies 'climate risks' as one of the core challenges for addressing what it calls South Africa's 'incomplete transition' and the accompanying legacy of racial exclusion. The Bank identifies the potential of the tourism sector for poverty alleviation and for achieving a more pro-poor development trajectory which underlines the importance of understanding the impacts of climate change in South Africa as a whole and specifically for the country's expanding tourism economy. Several projections have been offered as to the possible impacts on South Africa of climate change and global warming (Ziervogel et al., 2014). The World Bank (2018: v) argues climate change "will impose considerable costs on South Africa" and not least for the sector of tourism. It maintains that the country already "suffers the effects of climate change and vulnerability" (World Bank, 2018: 25). The country's risk exposure to climate change is elaborated as follows: "While temperatures in South Africa are expected to increase, rainfall patterns remain uncertain. Climate models project that South Africa's mean temperature will rise by about $0.5^{\circ} \mathrm{C}$ in coastal regions and $1{ }^{\circ} \mathrm{C}$ in the interior in the coming decades. Toward the end of the century, even under a best-case "high-mitigation" future, average temperatures in the interior could increase by up to $4^{\circ} \mathrm{C}$. Precipitation changes would cause drier conditions across the country under a "low mitigation" future (that is, the worst-case scenario), with regional variability possible. Under a "high-mitigation" future, models indicate wetter conditions in the central and eastern interior, and drier conditions over the rest of the country" (World Bank, 2018: 29).

\section{Policy Responses}

This section turns to review the national government's shifting policy response to climate change in South Africa as a whole and then specifically with reference to the tourism sector. Two sub-sections of material are provided relating to climate change policy as a whole and then towards tourism in particular. 


\section{The Development of Climate Change Policy and Responses in South Africa}

At the broadest level of policy discourse it should be recognized that South Africa has a relatively long-standing history of environmental focus. In 1996 the country formally recognized the importance of the environment and sustainable development in the post-apartheid Constitution. The South African constitution holds specifically that the environment be protected "for the benefit of present and future generations, through reasonable legislative and other measures" (Republic of South Africa, 1996: 9). This places a constitutional mandate on various spheres of national, provincial, and local government to ensure that all South Africans are afforded the opportunity to live in a safe environment for which the outcomes and impacts associated with climate change threaten to undermine. In acting upon this mandate the National Environmental Management Act was passed in 1998 to provide a guiding policy framework. The Act, which attempts to incorporate key elements of best international practice, accords significant emphasis to issues of environmentally sustainable development and growth as a result of South Africa's socio-economic challenges (Republic of South Africa, 1998).

Since the introduction of South Africa's post-apartheid constitution and the National Environmental Management Act, the country has continued to commit itself to environmental based sustainability practices and included climate change related mitigation undertakings by endorsing several international agreements (Patel, 2014). The most important is the United Nations Framework Convention on Climate Change which South Africa became a signatory of on 15 June 1993 and ratified on 29 August 1997 (Koch et al., 2007). Having committed to the United Nations Framework Convention on Climate Change, South Africa further elected to sign the Kyoto Protocol which sought to bind signatory states to undertake concrete action to reduce key emissions identified as being primarily responsible for anthropogenic or human induced climate change (Heuberger et al., 2007). The South African government further committed to the progress and fulfilment of the United Nations Millennium Development Goals (2000) (subsequently the Sustainable Development Goals) of which the seventh goal focusses specifically on environmental sustainability, the protection of key environmental resources, and the reduction of key biodiversity loss (Saarinen et al., 2011). In 2009 South Africa championed the Copenhagen Accord which officially acknowledges the dangers of climate change and the importance of the continuation of the work begun by the Kyoto Protocol in reducing carbon emissions (Lau et al., 2012). South Africa also took part in the development of the Cancun Agreements by submitting a national plan to begin the process of recording emissions, undertaking mitigation and adaptation-based actions to reduce the impacts and implications of climate change (Bhagwati, 2004). On 2 November 2016 South Africa ratified the Paris Agreement, after joining the landmark treaty in December 2015 following decades of international lobbying to see climate change taken seriously on the international stage (Bodansky, 2016). Overall, having consistently lobbied for recognising the importance of climate change the national government has enacted a range of climate change related policy initiatives. The most significant of these include the National Climate Change Response White Paper (2011), the Draft Climate Change Bill (2018), the Carbon Tax Act (2019), and the Draft National Climate Change Adaptation Strategy (2019).

Within such policy developments, the National Climate Change Response White Paper is regarded as the primary national policy document which aims to set out the key principles and overall strategic approach needing to be taken in order to respond to the issue of climate change. Nine overarching principles are set out by the National Climate Change Response White Paper in dealing with climate change:

1) Ensure that all international, national, provincial and local measures which focus on the issues associated with climate change are aligned in order to ensure effective mitigation and adaptation actions are undertaken.

2) Oversee the fair allocation of resources needed to adapt to the impacts and implications associated with climate change, as well as ensuring that the requisite costs of climate change are not disproportionate.

3) Consider those most vulnerable to the impacts and implications of climate change and seek to put in place measures to ensure that key groups such as women, children, the aged, sick, and physically challenged are accounted for.

4) Seek to continue to uplift and empower the poor and vulnerable within society while also ensuring that actions are sustainable socially, economically and environmentally.

5) Ensure that all actions and measures undertaken are sustainable in the long-term in order to ensure that key resources are still available for future generations.

6) Take a risk-averse approach to confronting climate change, and specifically apply a precautionary principle in the decision making process.

7) Enforce the polluter pays principle, which seeks to ensure that those who do undertake actions that emit carbon into the atmosphere pay the costs used to support or remedy the damage which takes place as a result.

8) Place increasing emphasis on public awareness surrounding the climate change issue in order to ensure informed participation to ensure support for mitigation and adaptation based undertakings.

9) Recognise the importance of a healthy environment and ecosystems which are invaluable in the manner in which they underpin a sustainable economy needed for socio-economic upliftment and stability.

In South Africa's Draft Climate Change Bill (2018) it is acknowledged the core purpose is to provide a coordinated direction for all spheres of government in dealing climate change. Such an undertaking is particularly important given the widespread scope of impacts and issues associated with the phenomenon, and in such regard a coordinated and well-integrated approach by all spheres of government is essential. The Draft Climate Change Bill also attempts to outline the key actions and parties necessary to increase South Africa's overall adaptive capacity, resilience and mitigation ability. The Bill attempts to specifically outline the key roles and responsibilities of provincial governments and local municipalities, which are set to be reviewed every five years given the shifting nature of climate change related challenges. The Carbon Tax Act (2019) represents one of the instruments outlined in the National Climate Change Response White Paper which seeks to play a role in reducing carbon dioxide based greenhouse emissions as part of the country's international commitment to act on climate 
change. Such an intervention makes use of the user pays principle which seeks to use the funds acquired by those whose activities contribute to increased carbon dioxide levels in the atmosphere for the purpose of funding initiatives that seek to remedy the impacts of emissions. It is the goal of such an instrument to strategically encourage the efficient use of energy and the appropriate incentive to reduce excessive energy consumption. Such a tax has specifically been imposed on activities that involve the combustion of fossil fuels, industrial processes that produce carbon emissions directly, and activities that produce fugitive emissions indirectly. The Act came into effect on 1 June 2019. The Draft National Climate Change Adaptation Strategy (2019) attempts to establish a clear pathway of objectives, actions or interventions, as well as final outcomes that are required in order to institutionalize adaptation-based initiatives as a means of reducing the risks associated with climate change. Table 2 summarises the key objectives identified by the Draft National Climate Change Adaptation Strategy. Of note is that it accords significant emphasis to risk reduction, capacity building, and resilience enhancement. This attempts to reinforce the importance of effective climate change adaptive policy, planning and action in long-term sustainable growth. The Draft National Climate Change Adaptation Strategy further outlines a suite of necessary provincial and local level adaptive actions.

Table 2. Summary of Key Objectives, Planned Interventions and Outcomes

of the National Climate Change Adaptation Strategy (Source: Republic of South Africa, 2019)

\begin{tabular}{|c|c|c|}
\hline ives & \begin{tabular}{|c|} 
Interventions \\
\end{tabular} & \\
\hline \multirow{2}{*}{$\begin{array}{c}\text { Objective } \\
1\end{array}$} & $\begin{array}{l}\text { Intervention 1: Reduce human, economic, environment, } \\
\text { physical and ecological infrastructure vulnerability and } \\
\text { build adaptive capacity. }\end{array}$ & $\begin{array}{l}\text { Outcome 1.1: Increased resilience and adaptive capacity achieved } \\
\text { in human, economic, environment, physical and ecological } \\
\text { infrastructure vulnerability. }\end{array}$ \\
\hline & \begin{tabular}{|l} 
Intervention 2: Develop a risk, early warning, \\
vulnerability and adaptation monitoring system for key \\
climate vulnerable sectors and geographic areas.
\end{tabular} & $\begin{array}{l}\text { Outcome 2.1: An early warning and monitoring system for key } \\
\text { climate vulnerable sectors and geographic areas developed and } \\
\text { implemented. }\end{array}$ \\
\hline \multirow{3}{*}{$\begin{array}{c}\text { Objective } \\
2\end{array}$} & $\begin{array}{l}\text { tervention 3: Develop vulnerability and resilience } \\
\text { ethodology framework that integrates biophysical and } \\
\text { cio-economic aspects of vulnerability and resilience. }\end{array}$ & $\begin{array}{l}\text { Outcome 3.1: An adaptation, vulnerability and resilience } \\
\text { framework developed and implemented across } 100 \% \text { of key } \\
\text { adaptation sectors. }\end{array}$ \\
\hline & \multirow{2}{*}{$\begin{array}{l}\text { Intervention 4: Facilitate mainstreaming of adaptation } \\
\text { responses into sectoral planning and implementation. }\end{array}$} & $\begin{array}{l}\text { Outcome 4.1: An effective adaptation planning that covers at least } \\
80 \% \text { of the South African sectors. }\end{array}$ \\
\hline & & $\begin{array}{l}\text { ne 4.2: Achieve } 100 \% \text { coverage of climate change } \\
\text { rations in sectoral operational plans. }\end{array}$ \\
\hline \multirow{2}{*}{$\begin{array}{l}\text { Objective } \\
3\end{array}$} & $\begin{array}{l}\text { Intervention 5: Promote research application, technology } \\
\text { development, transfer and adoption to support planning } \\
\text { and implementation. }\end{array}$ & $\begin{array}{l}\text { Outcome 5.1: Increased research output and technology uptake to } \\
\text { support planning and implementation. }\end{array}$ \\
\hline & $\begin{array}{l}\text { tervention 6: Build the necessary capacity and } \\
\text { Nareness for climate change response. }\end{array}$ & ange \\
\hline \multirow{4}{*}{$\begin{array}{c}\text { Objective } \\
4\end{array}$} & \multirow{2}{*}{$\begin{array}{l}\text { Intervention 7: Establish effective governance and } \\
\text { legislative processes to integrate climate change in } \\
\text { development planning. }\end{array}$} & $\begin{array}{l}\text { Outcome 7.1: Adaptation governance defined and legislated } \\
\text { through the Climate Change Act once approved by parliament. } \\
\begin{array}{l}\text { Outcome 7.2: Institutional support structures for climate change } \\
\text { adaptation strengthened. }\end{array}\end{array}$ \\
\hline & & civil society collaboration \\
\hline & $\begin{array}{l}\text { Intervention 8: Enable substantial flows of climate } \\
\text { change adaptation finance from various sources. }\end{array}$ & 1 adaptation \\
\hline & $\begin{array}{l}\text { Intervention 9: Develop and implement a monitoring and } \\
\text { evaluation (M\&E) system that tracks implementation of } \\
\text { adaptation actions and their effectiveness. }\end{array}$ & $\begin{array}{l}\text { Outcome 9.1: A national M\&E system developed and } \\
\text { implemented. }\end{array}$ \\
\hline
\end{tabular}

\section{Tourism and Climate Change Policy}

In the context of climate change and tourism policy development, it should be noted the South African government has acknowledged climate change represents one of the greatest threats to sustainable development (Department of Tourism, 2011a, 2011b). Moreover, policy-makers have conceded that if left unabated the potential threats associated with climate change have the potential to undo or undermine many of the positive advances made by South Africa in terms of expanding the country's tourism industry, and the subsequent jobs and economic growth that has come about as a result of the growth and development in the tourism sector (Rogerson, 2016). In the 2016 version of South Africa's National Tourism Sector Strategy document, it is observed that "South Africa's natural environment is one of its greatest tourism resources, and, therefore, the tourism industry needs to be actively involved in conserving and protecting it" (Department of Tourism, 2016: 8).

The Golder Associates report (2011) was a benchmark investigation in terms of formulating of tourism policy in South Africa. It provided the assessment baseline which led to the preparation of the country's first specific policy statements relating to the tourism sector. Such recognition is embodied in the Draft National Tourism and Climate Change Action Plan (2011) which seeks to give specific direction to key players within the tourism industry in terms of the actions that are necessary for dealing with climate change, and the issues that may directly or indirectly impact on the tourism industry. The key purpose was to begin the process of implementing actions to reduce climate change related threats. Its focus included improving industry understanding of its climate change vulnerability while also attempting to encourage the greening of the tourism economy with reduced carbon emissions. It was conceded that as a continual challenge, South Africa needed to continuously monitor and evolve the approaches taken to combating climate change within the confines of tourism. 
Overall, it is made clear in government policy documents that "climate change matters to South African tourism" (Department of Tourism, 2011a: 4). The pressing need to consider climate change impacts upon tourism stems ultimately from concerns about the competitive strengths of South African tourism (Reddy, 2011). In 2011 national government stated as follows: "Our geographic location away from most of our key markets, the heavy reliance we place on South Africa's environment in our positioning, and therefore in our visitor's expectations and experience, as well as the high proportion of fuel and energy costs in our product mix all mean that climate change is an issue of relevance for the sector" (Department of Tourism, 2011a: 74). National government thus has acknowledged the need for policy and action in relation to tourism and climate change in South Africa (Rogerson, 2016). It is recognised that the challenges presented by climate change cannot be the sole responsibility of one government department because effective integration of adaptation and mitigation measures demands the buy-in and prioritisation of climate change by all government departments and across all three spheres of government in South Africa. Indeed, it is conceded that effective action must also go beyond the scope of the tourism sector itself and more particularly given the highly diverse nature of the tourism economy as a result of the wide scope of products and services that underpin it. Stakeholder engagement through the process of public participation is not only encouraged but is in fact enshrined in South African legislation (Department of Environmental Affairs, 2011). More specifically, the country's concerns surrounding the issue of climate change and tourism are expressed in the National Tourism Sector Strategy the guiding policy framework for tourism development in the country along with the National Tourism and Climate Change Action Plan (Department of Tourism, 2011a). These national policy documents envision and essentially set forth the goal of establishing a low carbon and climate resilient tourism sector. Such a vision, however, is also crucially acknowledged to require an "ongoing", and "dynamic climate change policy environment" that prioritizes and is dependent upon five key outcomes. First, it involves an improved understanding of the vulnerabilities of tourism to the physical impacts of climate change in order to build resilience and adaptive capacity. Second, is a reduction in tourism based greenhouse gas emissions. The third depends on a fully informed tourism industry which will be brought about by consistent and effective industry outreach and communications. The fourth pertains to the crucial need to have a consistent, inclusive and cooperative approach to policy and framework implementation. Finally, the fifth outcome sees the country maintain an effective positioning within the county's key markets (Department of Tourism, 2011a, 2011b).

\section{CONCLUSION}

Globally climate change raises a number of critical questions and challenges for national governments and for the tourism industry as a whole, in particular for stakeholders and businesses (Becken, 2013; Nacipucha et al., 2017; Sifilo and Henama, 2017; Tervo-Kankare et al., 2018; Pandy and Rogerson, 2020). One recent study by the Organisation for Economic Cooperation and Development (OECD) concluded that "South Africa is one of the most vulnerable countries in the world with respect to projected climate change" (Glocker and Haxton, 2020: 30). The objective in this paper was to analyse climate change projections, and review the significance as well as potential ramifications of climate change for the South African tourism industry. In addition, the discussion sought to chart the shifting contours of national government policy towards climate change risks in South Africa in general and relating to the tourism sector more specifically. It is disclosed the threats of climate change are particularly concerning for several of South Africa's iconic tourism assets around nature-based tourism, biodiversity and coastal tourism. Overall the findings point to a conclusion that climate change presents a serious threat to South Africa, and potentially devastate much of the natural environment upon which key segments of the tourism economy are reliant.

The analysis discloses that since democratic transition in 1994 national government of South Africa has been at the forefront in supporting international efforts and obligations to address the challenge of climate change. This commitment has fed into specific policy development regarding tourism. Nevertheless it is observed also that policy development by national government specifically towards climate change and tourism has not progressed markedly since the appearance of the 2011 policy documents. To a large extent this lack of progress is an outcome of the overwhelming concentration given by recent government tourism policy in South Africa towards issues of inclusivity and transformation. Arguably, as shown by the COVID-19 crisis, there is an imperative need for a return to a broader policy perspective in South Africa, one which might seriously re-engage with the implications and threats posed by climate change to the country's increasingly fragile tourism sector (Rogerson and Rogerson, 2020b). Although the need to mainstream climate change issues into tourism policies has been recognised at national government level it remains that implementation measures are hampered severely both by capacity constraints and weak climate change measures at the local government level in South Africa (Rogerson, 2016; Glocker and Haxton, 2020; Pandy and Rogerson, 2020). In final analysis this supports the view expressed by Adu-Ampong et al. (2021) of the significance for undertaking further research on the nexus of climate change and tourism policy in sub-Saharan Africa.

\section{Acknowledgements}

Out thanks go to University of Johannesburg for financial support of this research and to Robbie, Dawn and Skye Norfolk for helpful contributions to this paper.

\section{REFERENCES}

Abrahams, D. (2019). Transformation of the tourism sector in South Africa: A possible growth stimulant?. GeoJournal of Tourism and Geosites, 26 (3), 821-830.

Adu-Ampong, E., Kimbu, A., \& Saarinen, J. (2021). Reconsidering 'sustainability' in tourism policy and planning in sub-Saharan Africa: A research agenda. In: E. Adu-Ampong \& A. Kimbu (Eds.). Sustainable Tourism Policy and Planning in Africa. Abingdon: Routledge, 175-186. Bai, R., Lam, J.C., \& Li, V.O. (2018). A review on health cost accounting of air pollution in China. Environment International, 120, $279-294$. 
Becken, S. (2013). A review of tourism and climate change as an evolving knowledge domain. Tourism Management Perspectives, 6, 53-62.

Bhagwati, J. (2004). Don't cry for Cancún. Foreign Affairs (January-February), 52-63.

Bodansky, D. (2016). The Paris climate change agreement: A new hope?. American Journal of International Law, 110 (2), $288-319$.

Carabine, E., Lemma, A., Dupar, M., Jones, L., Mulugetta, Y., Ranger, N., \& van Aalst, M. (2014). The IPCC's fifth assessment report What's in it for Africa. Climate \& Development Knowledge Network (CDKN), 1-33.

Conway, D., \& Vincent, K. (Eds). (2021). Climate Risk in Africa: Adaptation and Resilience. Cham, Switzerland: Palgrave Macmillan.

Davies, J. (2016). Exploring the factors and actors that contribute to the co-production of climate adaptation plans: A comparison of three municipalities in the Western Cape Province, South Africa. Unpublished PhD dissertation, University of Cape Town.

Driver, A., Maze, K., Lombard, A.T., Nel, J., Rouget, M., Turpie, J.K., Cowling, R.M., Desmet, P., Goodman, P., Harris, J., Jonas, Z., Reyers, B., Sink, K., \& Strauss, T. (2004). South African National Spatial Biodiversity Assessment 2004: Summary Report. Pretoria: South African National Biodiversity Institute.

Driver, A., Sink, K.J., Nel, J.L., Holness, S.H., Van Niekerk, L., Daniels, F., Jonas, Z., Majiedt, P.A., Harris, L., \& Maze, K. (2012). National Biodiversity Assessment 2011: An assessment of South Africa's biodiversity and ecosystems. Synthesis report. Pretoria: South African National Biodiversity Institute \& Department of Environmental Affairs.

Dube, K., Nhamo, G., \& Chirodzi, D. (2020). Climate change-induced droughts and tourism: Impacts and responses of Western Cape province, South Africa. Journal of Outdoor Recreation and Tourism, 100319.

Dube, K., Nhamo, G., \& Chirodzi, D. (2021). Rising sea levels and its implications on coastal tourism development in Cape Town, South Africa. Journal of Outdoor Recreation and Tourism, 33, 100346.

Engelbrecht, F.A., Marean, C.W., Cowling, R.M., Engelbrecht, C.J., Neumann, F.H., Scott, L., \& Franklin, J. (2019). Downscaling last glacial maximum climate over southern Africa. Quaternary Science Reviews, 226, 105879.

Fitchett, J.M. (2021). Climate change threats to urban tourism in South Africa. In C.M. Rogerson \& J.M. Rogerson (Eds.). Urban Tourism in the Global South: South African Perspectives. Cham, Switzerland, Springer Nature.

Fitchett, J.M., \& Hoogendoorn, G. (2018). An analysis of factors affecting tourists' accounts of weather in South Africa. International Journal of Biometeorology, 62, 2161-2172.

Fitchett, J.M., \& Mahlangu, M.M. (2019). Climate change threats to a floral wedding: Threats of shifting phenology to the South African wedding industry. Bulletin of Geography: Socio-Economic Series, 45, 7-23.

Giddy, J.K., \& Rogerson, C.M. (2018). Tracking SCUBA diving adventure tourism in South Africa. Euroeconomica, $37,41-56$.

Giddy, J.K., Fitchett, J.M., \& Hoogendoorn, G. (2017). Insight into American tourists' experiences with weather in South Africa. Bulletin of Geography: Socio-economic Series, 38, 57-72.

Glocker, D., \& Haxton, P. (2020). Leveraging Tourism Development for Sustainable and Inclusive Growth in South Africa. Paris: Organisation for Economic Co-operation and Development Working Paper No. 1621.

Golder Associates (2012). Vulnerability and Impact of Climate Change on Major Tourism Attractions and Activities: Baseline Assessment. Report No. 11613331-10989-2 for GIZ, Pretoria, South Africa.

Gómez-Martín, M.B. (2005). Weather, climate and tourism a geographical perspective. Annals of Tourism Research, 32 (3), $571-591$.

Gössling, S., Scott, D., \& Hall, C.M. (2013). Challenges of tourism in a low-carbon economy. Wiley Interdisciplinary Reviews: Climate Change, 4(6), 525-538.

Hall, C.M. (2008). Tourism and climate change: Knowledge gaps and issues. Tourism Recreation Research, 33 (3), $339-350$.

Heuberger, R., Brent, A., Santos, L., Sutter, C., \& Imboden, D. (2007). CDM projects under the Kyoto Protocol: A methodology for sustainability assessment-experiences from South Africa and Uruguay. Environment, Development and Sustainability, 9 (1), $33-48$.

Hoogendoorn, G., \& Fitchett, J.M. (2018). Tourism and climate change: A review of threats and adaptation strategies for Africa. Current Issues in Tourism, 21(7), 742-759.

Hoogendoorn, G., Grant, B., \& Fitchett, J. (2016). Disjunct perceptions?: Climate change threats in two-low lying South African coastal towns. Bulletin of Geography: Socio-Economic Series, 31, 59-71.

Ismail, S., \& Rogerson, J.M. (2016). Retrofitting hotels: Evidence from the Protea Hospitality Group of hotels within Gauteng, South Africa. African Journal of Hospitality, Tourism and Leisure, 5 (1), 1-14.

Kilungu, H., Leemans, R., Munishi, P.K., Nicholls, S., \& Amelung, B. (2019). Forty years of climate and land-cover change and its effects on tourism resources in Kilimanjaro National Park. Tourism Planning \& Development, 16 (2), 235-253.

Koch, I.C., Vogel, C., \& Patel, Z. (2007). Institutional dynamics and climate change adaptation in South Africa. Mitigation and Adaptation Strategies for Global Change, 12 (8), 1323-1339.

Lau, L.C., Lee, K.T., \& Mohamed, A.R. (2012). Global warming mitigation and renewable energy policy development from the Kyoto Protocol to the Copenhagen Accord - A comment. Renewable and Sustainable Energy Reviews, 16 (7), 5280-5284.

MacKellar, N., New, M., \& Jack, C. (2014). Observed and modelled trends in rainfall and temperature for South Africa: 1960-2010. South African Journal of Science, 110 (7-8), 1-13.

Madzwamuse, M. (2010). Climate Change Vulnerability and Adaptation Preparedness in South Africa. Cape Town: Heinrich Böll Stiftung South Africa.

Maúre, G., Pinto, I., Ndebele-Murisa, M., Muthige, M., Lennard, C., Nikulin, G., Dosio, A., \& Meque, A., (2018). The southern African climate under 1.5 C and $2 \mathrm{C}$ of global warming as simulated by CORDEX regional climate models. Environmental Research Letters, 13 (6), 1-12.

McKay, T. (2020). Locating great white shark tourism in Gansbaai, South Africa within the global shark tourism economy. In J.M. Rogerson \& G. Visser (Eds.), New Directions in South African Tourism Geographies. Cham, Switzerland: Springer, 283-296.

Mortreux, C., \& Barnett, J. (2009). Climate change, migration and adaptation in Funafuti, Tuvalu. Global Environmental Change, 19 (1), $105-112$.

Mushawemhuka, W., Rogerson, J.M., \& Saarinen, J. (2018). Nature-based operators' perceptions and adaptations to climate change in Hwange National Park, Zimbabwe. Bulletin of Geography: Socio-Economic Series, 42, 115-127.

Nacipucha, D., Ruhanen, L., \& Cooper, C. (2017). Adaption to climate change: A knowledge management approach. Anatolia, 28(3), 422-431.

Nicholson, S.E., Funk, C., \& Fink, A.H. (2018). Rainfall over the African continent from the 19th through the 21st century. Global and Planetary Change, 165, 114-127.

Ofoegbu, C., Chirwa, P., Francis, J., \& Babalola, F. (2017). Assessing vulnerability of rural communities to climate change: A review of implications for forest-based livelihoods in South Africa. International Journal of Climate Change Strategies and Management, 9 (3), 374-386.

Pandy, W.R. (2017). Tourism enterprises and climate change: Some research imperatives. African Journal of Hospitality, Tourism and Leisure, 6(4), 1-18. 
Pandy, W.R., \& Rogerson, C.M. (2018). Tourism and climate change in South Africa: An exploratory analysis of stakeholder perceptions of at risk tourism market segments. Euroeconomica, 37, 98-112.

Pandy, W.R., \& Rogerson, C.M. (2019). Urban tourism and climate change: Risk perceptions of business tourism stakeholders in Johannesburg, South Africa. Urbani izziv, 30(Supplement), 225-243.

Pandy, W.R., \& Rogerson, C.M. (2020). Tourism industry perspectives on climate change in South Africa. In J.M. Rogerson \& G. Visser (Eds.), New Directions in South African Tourism Geographies. Cham, Switzerland: Springer, 93-111.

Pang, S.F., McKercher, B., \& Prideaux, B. (2013). Climate change and tourism: An overview. Asia Pacific Journal of Tourism Research, $18(1-2), 4-20$.

Patel, Z. (2014). South Africa's three waves of environmental policy:(Mis) aligning the goals of sustainable development, environmental justice and climate change. Geography Compass, 8 (3), 169-181.

Prideaux, B., Thompson, M., \& Pabel, A. (2020). Lessons from COVID-19 can prepare global tourism for the economic transformation needed to combat climate change. Tourism Geographies, 22 (3), 667-678.

Reddy, M. (2012). Tourism and climate change risks: Opportunities and constraints in South Africa. MSc dissertation, University of the Witwatersrand. Johannesburg.

Rogerson, C.M. (2016). Climate change, tourism and local economic development in South Africa. Local Economy, 31(1-2), $322-331$.

Rogerson, C.M. (2020). Coastal and marine tourism in the Indian Ocean Rim Association states: Overview and policy challenges. GeoJournal of Tourism and Geosites, 29 (2), 715-731.

Rogerson, C.M., \& Rogerson, J.M. (2020a). Coastal tourism in South Africa: A geographical perspective. In J.M. Rogerson \& G. Visser (Eds.), New Directions in South African Tourism Geographies. Cham, Switzerland: Springer, 227-248.

Rogerson, C.M., \& Rogerson, J.M. (2020b). COVID-19 tourism impacts in South Africa: Government and industry responses. GeoJournal of Tourism and Geosites, 31 (3), 1083-1091.

Rogerson, J.M., \& Sims, S. (2012). The greening of urban hotels in South Africa: Evidence from Gauteng. Urban Forum, 23(3), $391-407$.

Rogerson, J.M., \& Visser, G. (2020). Recent trends in South African tourism geographies. In J.M. Rogerson \& G. Visser (Eds.), New Directions in South African Tourism Geographies. Cham, Switzerland: Springer, 1-14.

Romero-Lankao, P., Bulkeley, H., Pelling, M., Burch, S., Gordon, D.J., Gupta, J., Johnson, C., Kurian, P., Lecavalier, E., Simon, D., \& Tozer, L., (2018). Urban transformative potential in a changing climate. Nature Climate Change, 8 (9), 754-768.

Ruhanen, L., \& Shakeela, A. (2013). Responding to climate change: Australian tourism industry perspectives on current challenges and future directions. Asia Pacific Journal of Tourism Research, 18 (1-2), 35-51.

Saarinen, J., Rogerson, C.M., \& Manwa, H. (2011). Tourism and Millennium Development Goals: Tourism for global development?. Current Issues in Tourism, 14 (3), 201-203.

Saarinen, J., Hambira, W.L., Atlhopheng, J., \& Manwa, H. (2012). Tourism industry reaction to climate change in Kgalagadi South District, Botswana. Development Southern Africa, 29 (2), 273-285.

Scott, D. (2008). Climate change: Tourism destination dynamics. Tourism Recreation Research, 33(3), 354-355.

Scott, D., Hall, C.M., \& Gössling, S. (2019). Global tourism vulnerability to climate change. Annals of Tourism Research, 77, $49-61$.

Shakeela, A., \& Becken, S. (2015). Understanding tourism leaders' perceptions of risks from climate change: An assessment of policymaking processes in the Maldives using the social amplification of risk framework (SARF). Journal of Sustainable Tourism, 23 (1), 65-84.

Sifilo, P., \& Henama, U. (2017). Implications of climate change for tourism in Africa. GeoJournal of Tourism and Geosites, 20(2), 191-198.

Sinclair-Maragh, G. (2016). Climate change and the hospitality and tourism industry in developing countries. In M.A. Gonzalez-Perez \& L. Leonard (Eds.), Climate Change and the 2030 Corporate Agenda for Sustainable Development. Bingley, Emerald, 7-24.

Steyn, J.N., \& Spencer, J.P. (2012). Climate change and tourism: Implications for South Africa. African Journal for Physical, Health Education, Recreation and Dance, 18(1), 1-19.

Tervo-Kankare, K., Saarinen, J., Kimaro, M.E., \& Moswete, N.N. (2018). Nature-based tourism operators' responses to changing environment and climate in Uis, Namibia. African Geographical Review, 37(3), 273-282.

Tyson, P.D., \& Preston-Whyte, R.A. (2000). Weather and Climate of Southern Africa. Cape Town: Oxford University Press.

*** Department of Environmental Affairs (2011). National Climate Change Response White Paper. Pretoria: Department of Environmental Affairs.

*** Department of Environmental Affairs (2013). Long Term Adaptation Scenarios: Summary for Policy-makers. Pretoria: Department of Environmental Affairs.

*** Department of Environmental Affairs (2016). South Africa's $1^{\text {st }}$ Annual Climate Change Report. Pretoria: Department of Environmental Affairs.

*** Department of Environmental Affairs (2018). Draft Climate Change Bill. Pretoria: Department of Environmental Affairs.

*** Department of Science and Technology (2010). South African Risk and Vulnerability Atlas. Pretoria: Department of Science and Technology.

*** Department of Tourism (2011a). Draft National Tourism and Climate Change Action Plan. Pretoria: Department of Tourism.

*** Department of Tourism (2011b). National Tourism Sector Strategy. Pretoria: Department of Tourism.

*** Department of Tourism (2016). National Tourism Sector Strategy. Pretoria: Department of Tourism.

*** Republic of South Africa (1996). The Republic of South Africa's Constitution. Pretoria: Government Printer.

*** Republic of South Africa (1998). The National Environmental Management Act (NEMA). Pretoria: Government Printer.

*** World Bank (2018). An Incomplete Transition: Overcoming the Legacy of Exclusion in South Africa. Report No. 125838-ZA. Washington DC: The World Bank.

Ziervogel, C., New, M., Archer van Garderen, E., Midgley, G., Taylor, A., Hamann, R., Stuart-Hill, S., Myers, J., \& Warburton, M. (2014). Climate change impacts and adaptation in South Africa. Wiley Interdisciplinary Reviews: Climate Change, 5(5), 605-620. 